\section{Analysis of early relaparotomy in recipients of adult living donor liver transplantation}

\author{
Gokhan Ertugrul ${ }^{1 *}$, Atıf Tekin ${ }^{2}$ and Mahmut Zenciroglu² \\ ${ }^{1}$ Organ Transplantation Center, Medipol University Faculty of Medicine, Istanbul, Turkey \\ ${ }^{2}$ Department of General Surgery, Medipol University Faculty of Medicine, Istanbul, Turkey
}

Received: 19 July, 2021

Accepted: 23 August, 2021

Published: 24 August, 2021

*Corresponding author: Gokhan Ertugrul, Organ Transplantation Center, Medipol University Faculty of Medicine, Istanbul, Turkey, Tel: +902124607777; Fax: +902124706060; E-mail:mdgertugrul@gmail.com

ORCID: https://orcid.org/0000-0002-8351-4220

Keywords: Living donor liver transplantation; Early relaparotomy; Upper abdominal surgery; Elderly patients; Analysis

https://www.peertechz.com

\section{Check for updates}

\title{
Abstract
}

Background: While early relaparotomy following living donor liver transplantation (LDLT) is an important event and its outcomes are still unclear, the aim of this retrospective study is to investigate the causes and outcomes of early relaparotomy in recipients of adult living donor liver transplantations.

Materials and methods: Between April 2015 and April 2020 at Medipol University Medical Faculty Hospital Organ Transplantation Department, Istanbul, Turkey, 15 patients (9.3\%) who underwent early relaparotomy were studied retrospectively.

Results: Eight patients (53.3\%) had a history of upper abdominal surgery in the early laparotomy group. The most common cause of early relaparotomy had postoperative bleeding in 9 patients $(60 \%)$. The overall survival rate was $66.7 \%$. Mortality was higher in the group over 60 years old and with a history of upper abdominal surgery.

Conclusions: The history of upper abdominal surgery appears to be a risk factor for early relaparotomy. Also, previous upper abdominal surgery group and elderly patients group present with more mortality. We should be very careful in these groups.

\section{Introduction}

Living Donor Liver Transplantation (LDLT) was first reported in 1988 and transplantation with the right hepatic lobe was reported in 1994. Since that time, LDLT using the right lobe has become a standard treatment for end-stage liver disease in adults [1-3].

LDLT has been especially accepted in countries where the number of cadaveric donors is low, such as in Turkey.

LDLT is a very invasive procedure and the relaparotomy rates are higher. Reconstructions are often challenging because of the small vessels and biliary tracts of the cut graft liver in living donor liver transplantation [4].

Early relaparotomy after LDLT may have an important effect on morbidity and mortality [5].

The aim of this retrospective study is to investigate the causes and outcomes of early relaparotomy in recipients of adult LDLT.

\section{Material and methods}

\section{Patients}

In this study, only early relaparotomies after adult LDLT were evaluated. Between April 2015 and April 2020 at Medipol University Medical Faculty Hospital Organ Transplantation Department, Istanbul, Turkey, 15 patients (9.3\%) who underwent early relaparotomy were studied retrospectively.

In these patients were evaluated demographic features( age, sex, Body Mass Index (BMI)), clinical features(Primary diseases, Model for End-Stage Liver Disease (MELD) score, causes of early relaparotomy), and mortality rates.

The technical content of the research protocol was reviewed and approved by the ethical committee of the Istanbul Medipol University (Ethical Committee Approved Number: 10840098772.02-E.61900), and the protocols were performed in accordance with the Declaration of Helsinki. 


\section{Surgical procedure}

Each recipient underwent a Mercedes incision. After total hepatectomy, the donor right lobe was removed from the ice and placed in the abdomen. The graft and recipient's right hepatic veins were anastomosed using 5/0 Prolene stitches. The recipient's main portal vein and the graft right portal vein were anastomosed using 6/0 Prolene stitches. The vascular clamps were opened to allow reperfusion. The donor and recipient right hepatic arteries were microscopically anastomosed using individual 7/0 Prolene sutures. All vascular structures were normal on intraoperative color Doppler ultrasonography. Biliary reconstruction was performed using Roux-en-Y choledochojejunostomy or duct-to-duct choledochocholedochostomy using 6/0 polydioxanone stitches. At the end of the operation, hemostasis was achieved and Loop No 1 polydioxanone stitches were used for abdominal fascia closure.

\section{Immunosuppressive therapy}

For immunosuppressive therapy in all patients:

Calcineurin inhibitors (tacrolimus or cyclosporine) were used at life-long.

\section{Mycophenolate Mofetil was used in a first-year.}

Prednisolone was used in the first six months.

\section{Opportunistic infection prophylaxis}

Patients were given the $900 \mathrm{mg} /$ day Valganciclovir for cytomegalovirus prophylaxis in the first 100 days. Patients were given $400 \mathrm{mg} /$ day Sulfamethoxazole/trimethoprim for Pneumocystis Pneumonia prophylaxis in the first three months. Patients were given $100 \mathrm{mg} /$ day Fluconazole for candida prophylaxis in the first three months.

\section{Causes of early relaparatomy}

Early relaparotomy was defined as laparotomy within 30 days after LDLT in this study. Relaparotomy for postoperative bleeding was indicated for recipients with hemodynamic instability in spite of a blood transfusion. Vessel complications (hepatic arterial thrombosis, portal vein thrombosis) and biliary complications (biliary leakage) were detected by Doppler ultrasonography, Computed Tomography, and Magnetic Rezonas imaging.

\section{Post-transplant follow-up}

Patients received control once a week for the first month after discharge, and once every 15 days for the second month and monthly for the following months.

\section{Statistical analysis}

SPSS 22.0 (SPSS for Windows, 2007, Chicago) was used for statistical analysis. Continuous variables wich have normal distribution, were presented as mean \pm Standard deviation. Statistical analysis fort he parametric variables was performed by the Student' $\mathrm{s}$ T-test. The qualitative variables were given as percent and the correlation between categorical variables was investigated by the chi-square test and Fisher's exact test. Statistical significance level was defined as $\mathrm{P}<0.05$.

\section{Results}

Right lobe liver transplantation was performed in all patients. Fifteen patients (9.3\%) were done early relaparotomy.

The mean age of patients was $54.2 \pm 15.1$ years; $8(53.3 \%)$ of the patients were male.

The mean BMI of patients was $25.9 \pm 4.7 \mathrm{~kg} / \mathrm{m} 2$ (kilogram per square meter).

The mean MELD scores of patients was $18.4 \pm 7$.

The indications for liver transplantation were liver cirrhosis due to hepatitis $\mathrm{B}$ virus infection in six patients $(40 \%)$, liver cirrhosis due to hepatitis $\mathrm{C}$ virus infection in four patients (26.6\%), cryptogenic liver cirrhosis in three patients $(20 \%)$, and alcoholic liver cirrhosis in two patients (13.3\%).

The indications for early relaparotomy were postoperative bleeding in nine patients $(60 \%)$, biliary leakage in four patients $(26.7 \%)$, and vascular complications in two patients (13.3\%).

In the postoperative bleeding group there were four patients in Vena Cava (44.4\%), two patients from portal vein $(22.2 \%)$, and three patients in the omental area (33.4\%).

In the biliary leakage group, all biliary leakages were caused by biliary anastomosis.

In the vascular complication group, early relaparotomy for hepatic artery thrombosis was performed in one patient $(50 \%)$, and early relaparotomy for portal vein thrombosis was performed in one patient (50\%).

Table 1 shows the demographic and clinical findings.

Eight patients (53.3\%) had a history of upper abdominal surgery in the early laparotomy group.

Table 1: Demographic and clinical findings.

\begin{tabular}{|c|c|}
\hline & $\begin{array}{l}\text { Early Relaparatomy } \\
\qquad(\mathrm{n}=15)\end{array}$ \\
\hline Age (years) & $54.2 \pm 15.1$ \\
\hline Male/female (n/\%) & $8(53.3 \%) / 7(46.7 \%)$ \\
\hline $\begin{array}{c}\text { Body mass index kilogram per } \\
\text { square meter }\left(\mathrm{kg} / \mathrm{m}^{2}\right)\end{array}$ & $25.9 \pm 4.7$ \\
\hline $\begin{array}{l}\text { Model for end-stage liver } \\
\text { disease } \\
\text { (MELD ) score (mean /SD) }\end{array}$ & $18.4 \pm 7$ \\
\hline Primary diseases (n/\%) & $\begin{array}{ll}\text { - } & \text { Liver cirrhosis-hepatitis B } 6(40 \%) \\
\text { - } & \text { Liver cirrhosis-hepatitis C } 4(26.6 \%) \\
\text { - } & \text { Cryptogenic cirrhosis } 3(20 \%) \\
\text { - } & \text { Alcoholic cirrhosis } 2(13.3 \%)\end{array}$ \\
\hline $\begin{array}{l}\text { Causes of early relaparotomy } \\
\qquad(\mathrm{n} / \%)\end{array}$ & $\begin{array}{ll}\text { - } & \text { Postoperative Bleeding } 9(60 \%) \\
\text { - } & \text { Biliary Leakage } 4(26.7 \%) \\
\text { - } & \text { Vascular Complications } 2(13.3 \%)\end{array}$ \\
\hline Mortality (n/\%) & $5(33.3 \%)$ \\
\hline Follow-Up Period(Month ) & $22.4 \pm 21.6$ \\
\hline
\end{tabular}


The mean follow-up time was $22.4 \pm 21.6(1-60)$ months.

The mean overall survival rate was $66.7 \%$. Mortality was higher in the group over 60 years old and with a history of upper abdominal surgery.

Table 2 shows the comparison of mortal group and nonmortal groups.

Figure 1 shows the effect of age on cumulative overall survival.

Figure 2 shows the effect of the history of upper abdominal surgery on cumulative overall survival.

\section{Discussion}

Complications after LDLT are extremely important for graft and patient survival. Early relaparotomy performed on recipient patients is a serious condition. New anastomoses may be damaged during relaparotomy, therefore, graft and patient loss may occur. In literature, relaparotomy rates after LDLT were reported to range from $9.2 \%$ to $34 \%$ [6-8]. In the current

Table 2: Comparison of mortal group and nonmortal group.

\begin{tabular}{|c|c|c|c|}
\hline & $\begin{array}{c}\text { Mortal Group } \\
(\mathrm{n} / \%) \\
5 / 33.3 \%\end{array}$ & $\begin{array}{l}\text { Nonmortal } \\
\text { Group } \\
\text { (n/\%) } \\
10 / 66.7 \%\end{array}$ & p value \\
\hline $\begin{array}{l}\text { Age (year) } \\
(<60 / \geq 60)\end{array}$ & $-/ 5(100 \%)$ & $8(80 \%) / 2(20 \%)$ & 0.007 \\
\hline $\begin{array}{c}\text { Sex (Male/ Female) } \\
(\mathrm{n} / \%)\end{array}$ & $3(60 \%) / 2(40 \%)$ & $5(50 \%) / 5(50 \%)$ & 0.573 \\
\hline $\begin{array}{l}\text { Model for end-stage liver disease } \\
\qquad(\text { MELD ) score } \\
(<20 / \geq 20)\end{array}$ & $4(80 \%) / 1(20 \%)$ & $5(50 \%) / 5(50 \%)$ & 0.580 \\
\hline $\begin{array}{l}\text { Body mass index kilogram per } \\
\text { square meter }\left(\mathrm{kg} / \mathrm{m}^{2}\right) \\
(<30 / \geq 30)\end{array}$ & $3(60 \%) / 2(40 \%)$ & $8(80 \%) / 2(20 \%)$ & 0.560 \\
\hline History of Upper Abdominal Surgery & $5(100 \%) /-$ & $3(30 \%) / 7(70 \%)$ & 0.026 \\
\hline
\end{tabular}
$(+/-)(n / \%)$

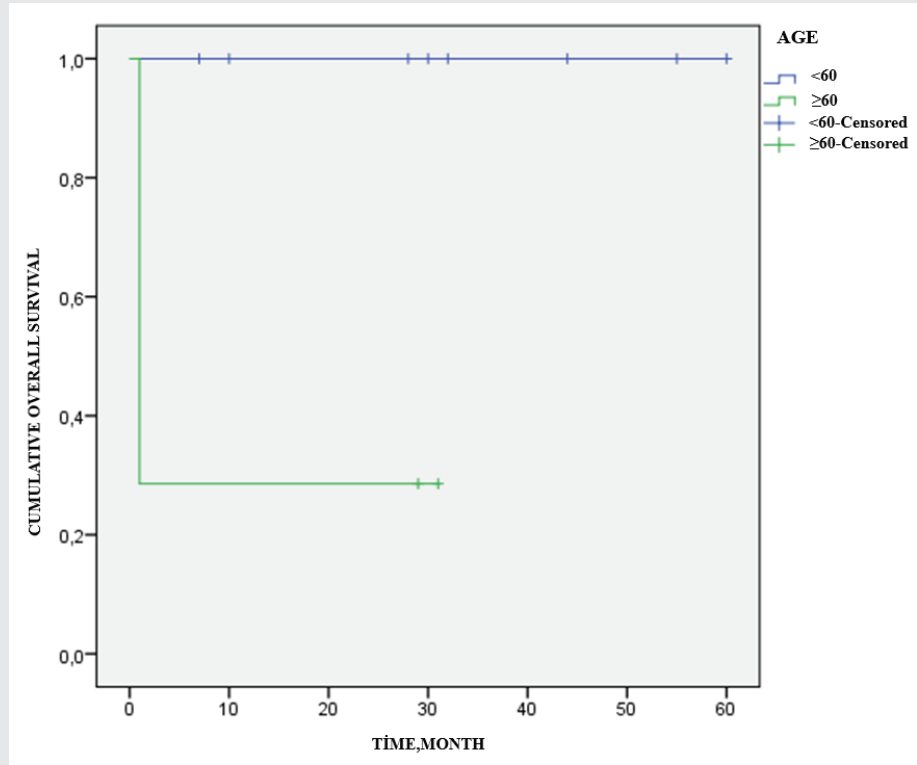

Figure 1: Effect of Age on Cumulative Overall Survival.

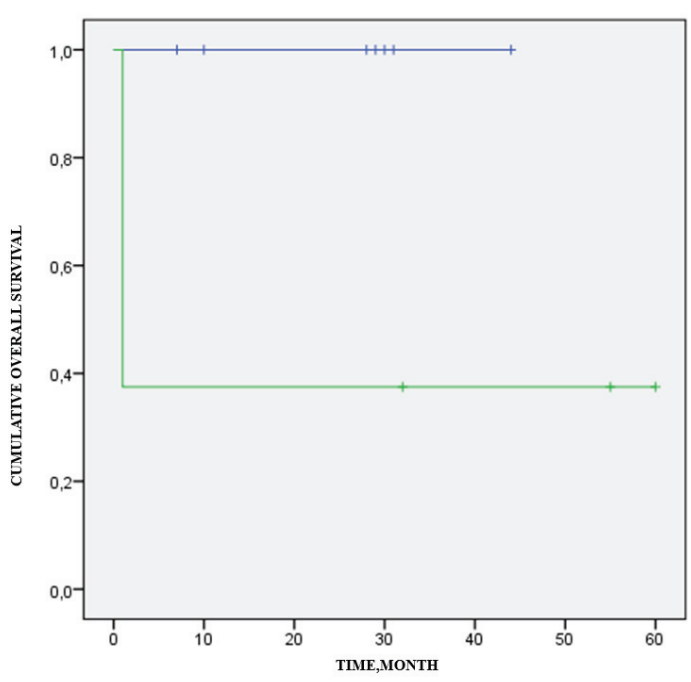

HISTORY OF UPPER $\neg$ No + NO-Censored - YEs-Censored

Figure 2: Effect of The History of Upper Abdominal Surgery on Cumulative Overal Survival.

study, 15 adult patients (9.3\%) were detected who underwent early relaparotomy after LDLT.

History of upper abdominal surgery, prolonged operative time, and surgical site infection were independent risk factors for early relaparotomy in the literature $[9,10]$. In our study, eight patients $(53.3 \%)$ had a history of upper abdominal surgery in the early laparotomy group.

Indications for early relaparotomy are generally postoperative bleeding, vessel complications, biliary complications, and intra abdominal infections [8-10].

Relaparotomy rates related to postoperative bleeding after LDLT, were reported to range from $40 \%$ to $50 \%$, in the literature [6-8]. Postoperative bleeding may be caused by prolonged coagulopathy and surgical technique. Also, other factors in the literature were; the high MELD score, intraoperative high blood loss, and intraoperative high blood transfusions [9-14]. The only risk factor in our study was the surgical technique. Other factors were not independent risk factors for early relaparotomy. In the current study, postoperative bleeding associated with relaparotomy rates were $60 \%$. In the postoperative bleeding group there were four patients in Vena Cava $(44.4 \%)$, two patients from portal vein $(22.2 \%)$, and three patients in the omental area (33.4\%).

Relaparotomy rate related to biliary leakage after LDLT was reported to range from $20 \%$ to $40 \%$, in the literature $[8,15]$. In the current study, biliary leakage was $26.7 \%$. All biliary leakages were caused by biliary anastomosis.

Relaparotomy rates related to vessel complications after LDLTs were reported to range from $19.2 \%$ to $27.3 \%$, in the literature $[6-8,16]$. In our study, vascular complications were $13.3 \%$. Early relaparotomy for hepatic artery thrombosis was performed in one patient $(50 \%)$, and early relaparotomy for portal vein thrombosis was performed in one patient (50\%). 
Survival rates were low in groups that underwent early relaparotomy in all studies in the literatüre. The survival rates of those cases were $61.5 \%$ and $67.3 \%$ [6-8].

In our study, the mean follow-up time was $22.4 \pm 21.6$ (160 ) months and the overall survival rate was $66.7 \%$. Mortality was higher in the group over 60 years old and with a history of upper abdominal surgery. All of the patients died of sepsis.

Our study has several limitations. First, this study was retrospective and secondly, the number of cases were small.

\section{Conclusion}

Despite the limitations described in the discussion, the history of upper abdominal surgery appears to be a risk factor for early relaparotomy. Also, previous upper abdominal surgery group and elderly patients group present more mortality, and we should be very careful especially in these groups. Gentle dissection and good hemostasis are essential in these groups.

\section{Ethics committee approval}

Ethics committee approval was received for this study from the Istanbul Medipol University Hospital (Decision date: 27.01.2021)

\section{Informed consent}

Written informed consent was obtained from the patients who participated in this study.

\section{Author contributions}

Concept - G.E., A.T.; Design - G.E., A.T.; Supervision - G.E., M.Z.; Resource - G.E., M.Z., A.T.; Materials - G.E., M.Z., A.T.; Data Collection and/or Processing G.E., M.Z., A.T.; Analysis and/or Interpretation - G.E., A.T.; Literature Search - G.E., M.Z.; Writing - G.E.; Critical Reviews - G.E., M.Z., A.T.

\section{References}

1. Hashikura Y, Makuuchi M, Kawasaki S, Matsunami H, lkegami T, et al. (1994) Successful living-related partial liver transplantation to an adult patient Lancet 343: 1233-1234. Link: https://bit.ly/3guLQVF

2. Liu CL, Fan ST, Lo CM, Wi W, Chan SC, et al. (2006) Operative outcomes of adult-to-adult right lobe live donor liver transplantation: a comparative study with cadaveric whole-graft liver transplantation in a single center. Ann Surg 243: 404-410. Link: https://bit.ly/2Wltsrf

3. Yamaoka Y, Washida M, Honda K, Tanaka K, Mori K, et al. (1994) Liver transplantation using a right lobe graft from a living related donor. Transplantation 57: 1127-1130. Link: https://bit.ly/38axi94

4. Kawaguchi Y, Sugawara Y, Akamatsu N, Kaneko J, Hamada T, et al. (2014) Impact of early reoperation following living-donor liver transplantation on graft survival. Plos One 9: e109731. Link: https://bit.ly/3DmWwj8

5. Ikegami T, Shirabe K, Yoshiya S, Yoshizumi T, Ninomiya M, et al. (2012) Bacterial sepsis after living donor liver transplantation: the impact of early enteral nutrition. J Am Coll Surg 214: 288-295. Link: https://bit.ly/3guS1ce
6. Yoshiya S, Shirabe K, Kimura K, Yoshizumi T, Ikegami T, et al. (2012) The causes, risk factors, and outcomes of early relaparotomy after living-donor liver transplantation. Transplantation 94: 947-952. Link: https://bit.ly/3zciYJ6

7. Hara T, Soyama A, Hidaka M, Kitasato A, Ono S, et al. (2016) Analysis of Early Relaparotomy Following Living Donor Liver Transplantation. Liver Transpl 22: 1519-1525. Link: https://bit.ly/3mtc3rl

8. Hendriks HG, van der Meer J, de Wolf JT, Peeters PM, Porte RJ, et al. (2005) Intraoperative blood transfusion requirement is the main determinant of early surgical re-intervention after orthotopic liver transplantation. Transpl Int 17 673-679. Link: https://bit.ly/3DdtfHh

9. Neumayer L, Hosokawa P, Itani K, El-Tamer M, Henderson WG, et al. (2007) Multivariable predictors of postoperative surgical site infection after general and vascular surgery: results from the patient safety in surgery study. $\mathrm{J} \mathrm{Am}$ Coll Surg 204: 1178-1187. Link: https://bit.ly/3DmWEiC

10. Okada N, Sanada Y, Onishi Y, Urahashi T, Ihara Y, et al. (2019) The Causes and Outcomes of Early Relaparotomy Following Pediatric Living Donor Liver Transplantation. Liver Transpl 25: 1066-1073. Link: https://bit.ly/3grXdOg

11. Thompson MA, Redden DT, Glueckert L, Smith AB, Crawford JH, et al. (2014) Risk factors associated with reoperation for bleeding following liver transplantation. HPB Surg 2014: 816246. Link: https://bit.ly/3zf1GLp

12. Liang TB, Bai XL, Li DL, Li JJ, Zheng SS (2007) Early postoperative hemorrhage requiring urgent surgical reintervention after orthotopic liver transplantation. Transplant Proc 39: 1549-1553. Link: https://bit.ly/3zcJlhX

13. Park C, Huh M, Steadman RH, Cheng R, Hu KQ, et al. (2010) Extended criteria donor and severe intraoperative glucose variability: association with reoperation for hemorrhage in liver transplantation. Transplant Proc 42: 17381743. Link: https://bit.ly/3Dgjbh4

14. Kappa SF, Gorden DL, Davidson MA, Wright JK, Guillamondegui OD (2010) Intraoperative blood loss predicts hemorrhage related reoperation after orthotopic liver transplantation. Am Surg 76: 969-973. Link: https://bit.ly/2XMsncx

15. Soong RS, Chan KM, Chou HS, Wu TJ, Lee CF, et al. (2012) The risk factors for early infection in adult living donor liver transplantation recipients. Transplant Proc 44: 784-786. Link: https://bit.ly/3sFLh02

16. Khalaf H (2010) Vascular complications after deceased and living donor live transplantation: a single-center experience. Transplant Proc 42: 865-870. Link: https://bit.ly/3gu2Lrn

Discover a bigger Impact and Visibility of your article publication with Peertechz Publications

Highlights

* Signatory publisher of ORCID

* Signatory Publisher of DORA (San Francisco Declaration on Research Assessment)

* Articles archived in worlds' renowned service providers such as Portico, CNKI, AGRIS, TDNet, Base (Bielefeld University Library), CrossRef, Scilit, J-Gate etc.

* Journals indexed in ICMJE, SHERPA/ROMEO, Google Scholar etc.

* OAI-PMH (Open Archives Initiative Protocol for Metadata Harvesting)

* Dedicated Editorial Board for every journal

* Accurate and rapid peer-review process

* Increased citations of published articles through promotions

* Reduced timeline for article publication

Submit your articles and experience a new surge in publication services (https://www.peertechz.com/submission).

Peertechz journals wishes everlasting success in your every endeavours.

Copyright: @ 2021 Ertugrul G, et al. This is an open-access article distributed under the terms of the Creative Commons Attribution License, which permits unrestricted use, distribution, and reproduction in any medium, provided the original author and source are credited. 